\title{
Pseudouridine formation in archaeal RNAs: The case of Haloferax volcanii
}

\author{
IAN K. BLABY, ${ }^{1,4,5}$ MRINMOYEE MAJUMDER, ${ }^{2,4}$ KUNAL CHATTERJEE, $^{2}$ SUJATA JANA, ${ }^{2}$ HENRI GROSJEAN, ${ }^{3}$ \\ VALÉRIE DE CRÉCY-LAGARD, ${ }^{1,6}$ and RAMESH GUPTA ${ }^{2,6}$ \\ ${ }^{1}$ Department of Microbiology \& Cell Science, University of Florida, Gainesville, Florida 32611-0700, USA \\ ${ }^{2}$ Department of Biochemistry and Molecular Biology, Southern Illinois University, Carbondale, Illinois 62901-4413, USA \\ ${ }^{3}$ Université Paris 11, IGM, CNRS, UMR 8621, Orsay, F 91405, France
}

\begin{abstract}
Pseudouridine $(\Psi)$, the isomer of uridine, is commonly found at various positions of noncoding RNAs of all organisms. $\Psi$ residues are formed by a number of single- or multisite specific $\Psi$ synthases, which generally act as stand-alone proteins. In addition, in Eukarya and Archaea, specific ribonucleoprotein complexes, each containing a distinct box H/ACA guide RNA and four core proteins, can produce $\Psi$ at many sites of different cellular RNAs. Cbf5 is the core $\Psi$ synthase in these complexes. Using Haloferax volcanii as an archaeal model organism, we show that, contrary to eukaryotes, the Cbf5 homolog (HVO_2493) is not essential in this archaeon. The Cbf5-deleted strain of $H$. volcanii completely lacks $\Psi$ at positions 1940, 1942, 2605, and 2591 (Escherichia coli positions 1915, 1917, 2572, and 2586) of its $23 S$ rRNA, and contains reduced steady-state levels of some box H/ACA RNAs. Archaeal Cbf5 is known to have tRNA $\Psi 55$ synthase activity in vitro but we could not confirm this activity in vivo in $H$. volcanii. Conversely, the Pus10 (previously PsuX) homolog (HVO_1979), which can produce tRNA $\Psi 55$, as well as $\Psi 54$ in vitro, is shown here to be essential in $H$. volcanii, whereas the corresponding tRNA $\Psi 55$ synthases, Pus4 and TruB, are not essential in yeast and $E$. coli, respectively. Finally, we demonstrate that HVO_1852, the TruA/Pus3 homolog, is responsible for the pseudouridylation of position 39 in $H$. volcanii tRNAs and that the corresponding gene is not essential.
\end{abstract}

Keywords: pseudouridine synthase; RNA modification; Cbf5; Pus10; TruA; Pus3

\section{INTRODUCTION}

Pseudouridine $(\Psi)$, the post-transcriptional C5-ribosyl isomer of uridine, is one of the most common modifications identified in a wide range of RNA species and in all domains of life (Charette and Gray 2000; Grosjean 2009; Cantara et al. 2011). $\Psi$ modifications are very abundant in tRNAs. In addition to the near ubiquitous $\Psi 55$ found in tRNAs of Archaea, Bacteria, Eukarya, and most of the organelles, $\Psi$ is found at several other positions of tRNA (Juhling et al. 2009). $\Psi$ modifications are plentiful in rRNAs, particularly in eukaryotes with $\sim 100$ identified in mammals and $\sim 50$ found in Saccharomyces cerevisiae (Cantara et al. 2011). $\Psi$ residues appear to be located specifically at functionally

\footnotetext{
${ }^{4}$ These authors contributed equally to this work.

${ }^{5}$ Present address: Department of Chemistry and Biochemistry, University of California, Los Angeles, CA 90095-1569, USA.

${ }^{6}$ Corresponding authors.

E-mail rgupta@siumed.edu.

E-mail vcrecy@ufl.edu.

Article published online ahead of print. Article and publication date are at http://www.rnajournal.org/cgi/doi/10.1261/rna.2712811.
}

important positions (Ofengand et al. 2001b; Decatur and Fournier 2002; Karijolich and Yu 2010).

Although the biological role of many $\Psi$ residues remains unknown, the modification is thought to be required for RNA structure and stability. Indeed, the ability of $\Psi$ residues to form an additional hydrogen bond compared to uridine, coupled with the property of augmenting local RNA stacking, causes the localized phosphodiester structure to become more rigid, contributing to overall RNA structure stabilization (Davis 1995; Yarian et al. 1999). Structural studies have suggested that, while the presence of pseudouridine modifications does not affect the overall three-dimensional structure of tRNA (Harrington et al. 1993; Arnez and Steitz 1994), the local structure near the site of modification is affected (Auffinger and Westhof 1997). The presence of $\Psi$ in the anticodon helps foster proper codon-anticodon interactions, which may increase translational accuracy, and the presence of $\Psi$ at positions $38 / 39$ of tRNA has a direct influence on codon reading and frameshifting (Zerfass and Beier 1992; Lecointe et al. 2002; Namy et al. 2005). $\Psi$ modifications in rRNAs can affect both ribosome biogenesis and 
translation accuracy (Decatur and Fournier 2002; BaudinBaillieu et al. 2009).

Six distinct pseudouridine synthase families have been identified to date on the basis of protein sequence similarity: TruA, TruB, TruD, RluA, RsuA, and Pus10 (Mueller and Ferre-D'Amare 2009). Predicting the substrate specificity of any given pseudouridine synthase is, however, difficult. Different proteins of the same family can produce $\Psi$ at different positions (Hamma and Ferre-D'Amare 2006; Mueller and Ferre-D'Amare 2009). The annotation of $\Psi$ modification genes is all the more difficult given that examples of nonorthologous displacements are frequent. In Escherichia coli and S. cerevisiae pseudouridylation of position 55 of tRNA is catalyzed by TruB and Pus4, respectively (Nurse et al. 1995; Becker et al. 1997), both members of Cluster of Orthologous Group (COG) 0130 (Tatusov et al. 2003). In Archaea however the unrelated Pus10 family of proteins belonging to COG 1258 seems to modify both positions 54 and 55 of tRNA (Roovers et al. 2006; Gurha and Gupta 2008).

Specific $\Psi$ residues in eukaryal and archaeal rRNAs and in eukaryal snRNAs can also be introduced by box H/ACA RNPs. The H/ACA RNPs comprise four core proteins and a modification-specific guide RNA containing between one and three hairpins (Dennis and Omer 2005; Yu et al. 2005; Meier 2006; Karijolich and Yu 2008; Li 2008; Hamma and Ferre-D'Amare 2010; Kiss et al. 2010). Cbf5, a member of the TruB family (COG 0130), is the pseudouridine synthase in the RNP, which together with Nop10, L7Ae (Nhp2 in Eukarya), and Gar1 forms a site-specific complex. Box H/ACA RNA-guided in vitro pseudouridylation systems using recombinant Pyrococcus furiosus, Pyrococcus abyssi, and Methanocaldococcus jannaschii proteins have been established (Baker et al. 2005; Charpentier et al. 2005; Gurha et al. 2007; Muller et al. 2008). However, Cbf5, in addition to its RNA-guided activity, also produces $\Psi$ at position 55 in tRNAs and in a 23S rRNA fragment in vitro in a guide RNA-independent manner. This guide RNA-independent activity of Cbf5 either requires or is enhanced by association with Gar1 and Nop10 (Roovers et al. 2006; Gurha et al. 2007; Muller et al. 2008).

In Eukarya the Cbf5 encoding gene is essential (Jiang et al. 1993; Giordano et al. 1999), which may be due to multiple roles of H/ACA RNPs in ribosome biogenesis, premRNA splicing, and telomere maintenance (Meier 2005; Karijolich and Yu 2008). Indeed, Cbf5 (Nap57 in mice) was originally identified in S. cerevisiae as a low affinity centromere binding protein, which is essential for cell viability (Jiang et al. 1993; Meier and Blobel 1994; Heiss et al. 1998). Orthologs of cbf5 are essential in yeast and Drosophila melanogaster, and its disruption is embryonic lethal in mice (Jiang et al. 1993; Phillips et al. 1998; Giordano et al. 1999; He et al. 2002).

Most of the information on the role of Cbf5 and proteinalone $\Psi$ synthases in Archaea is based on bioinformatic, biochemical, or structure-based data. The essentiality and function of these proteins in vivo is therefore still undetermined in this domain of life. We set out to determine the in vivo role of Cbf5 in $\Psi$ synthesis as well as of other $\Psi$ synthases using the model archaeon $H$. volcanii. Indeed, sequences of the nearly complete set of tRNAs with associated modifications have been determined in this archaeon (Gupta 1984, 1986) and the positions of $\Psi$ s in $23 S$ rRNA can be inferred by comparison with other haloarchaea (Ofengand and Bakin 1997; Del Campo et al. 2005; Kirpekar et al. 2005 and http://people.biochem.umass.edu/fournierlab/ 3 dmodmap/heneqlsu.php). H. volcanii $16 \mathrm{~S}$ rRNA does not contain $\Psi$ (Kowalak et al. 2000). $\Psi$ synthases for most of these $\Psi$ have also been predicted in the $H$. volcanii genome using a bioinformatic approach (Grosjean et al. 2008). In this work, we achieved the deletion of cbf5 (HVO_2493) (H. volcanii ORFs are as annotated in http://archaea.ucsc. edu and Hartman et al. 2010) and demonstrated that Cbf5 is responsible for the introduction of $\Psi$ at multiple positions in the $23 \mathrm{~S}$ rRNA, but for none of the $\Psi$ s at common positions of tRNAs. We also made efforts to create genomicdeletions of certain other $\Psi$ synthases, to determine their role in producing these non-Cbf5-dependent $\Psi$ s in tRNAs. We show that pus10 (HVO_1979), the gene for tRNA $\Psi 54$ and $\Psi 55$ synthase (Gurha and Gupta 2008), is essential in $H$. volcanii. We also show that the $H$. volcanii TruA/Pus3 homolog (HVO_1852) is indeed responsible for the introduction of $\Psi 39$ in tRNA. Finally we show that Cbf5 is needed for stabilization of box H/ACA RNAs that are predicted to guide $\Psi$ formation in $23 \mathrm{~S}$ rRNA.

\section{RESULTS AND DISCUSSION}

\section{HVO_2493, encoding the Cbf5 homolog, is not essential in $H$. volcanii}

The H. volcanii cbf5 homolog HVO_2493 was deleted using a published method (Allers et al. 2004), modified slightly to expedite the preliminary cloning steps (Blaby et al. 2010). Deletion of HVO_2493 was confirmed by PCR using two primer pairs, one designed to anneal outside the deleted fragment and the other within (Fig. 1B,C), and independently verified by Southern hybridization (Fig. 1D). These data indicate that $c b f 5$ is dispensable in $H$. volcanii. However, as shown in Figure 1E, deletion of $c b f 5$ caused a slight decrease in growth rate (from $0.03 \mathrm{~h}^{-1}$ in the wild-type [WT] strain to $0.02 \mathrm{~h}^{-1}$ in the mutant), although the final growth yield is not affected. To rescue the effects of the $c b f 5$ deletion, a derivative of the $\Delta c b f 5$ strain was created (Fig. 1A,D), which contained a plasmid-borne copy of $c b f 5$. The growth rate was restored to WT levels when $c b f 5$ was expressed in trans in the mutant strain (Fig. 1E). A well-established role of $\Psi$ residues is to maintain tertiary structure. If the absence of Cbf5 influenced the stability of the rRNA molecule, the $H$. volcanii $\Delta c b f 5$ strain could become more sensitive to altered salt concentrations or to temperature extremes. 

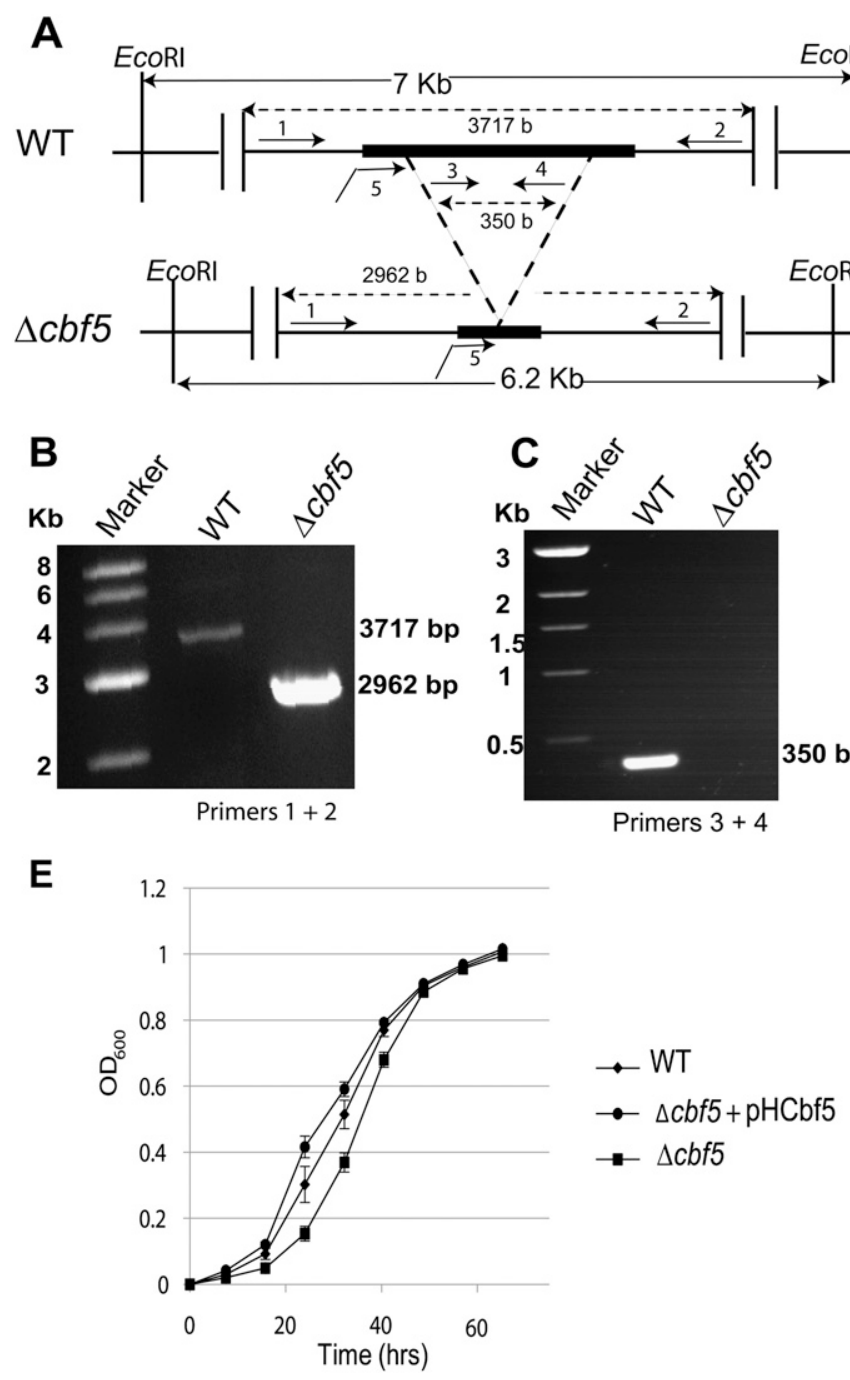

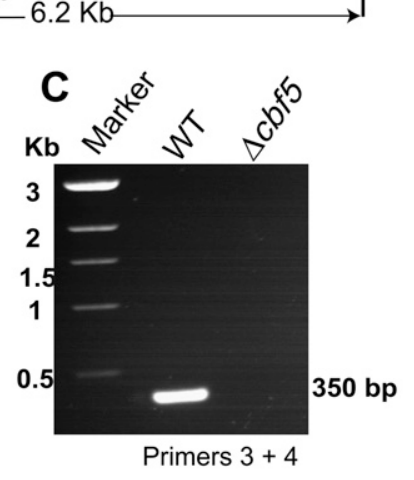

bp$$
\text { (1) }
$$

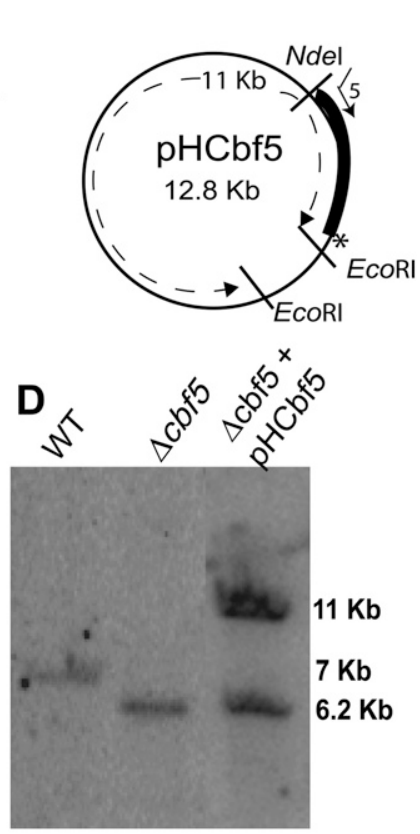

FIGURE 1. $c b f 5$-deleted strain of $H$. volcanii is viable. Deletion of the $c b f 5$ gene was confirmed by three independent methods. (A) Schematics to show HVO_2493 (thick lines) in the genomes of wild-type (WT) and $c b f 5$-deleted ( $\Delta c b f 5)$ strains and on plasmid pHCbf5. EcoRI and NdeI (in plasmid) sites are marked. Positions of primers 1-5 (Cbf5_Ext_Fwd, Cbf5_Ext_Rev, Cbf5_Int_Fwd, Cbf5_Int_Rew, and HVCBF5-F, respectively) are shown by arrows. The arrow direction indicates $5^{\prime}$ to $3^{\prime}$ direction of the primers. Segment between broken lines is deleted in the $\Delta c b f 5$ strain. The His-tag at the $\mathrm{C}$ terminus of the Cbf5 protein is indicated by an asterisk. Approximate lengths of the segments are indicated but are not drawn to a scale. (B) PCR products using primers designed to anneal outside the gene (primers 1 and 2 in $A$ ) confirm a genomic rearrangement of correctly predicted sizes in WT and mutant strains. (C) PCR products using primers designed to anneal within the target gene (primers 3 and 4 in A) show the absence of the HVO_2493 segment in the mutant and its presence in the WT strain. (D) Southern hybridization is consistent with loss of the gene in mutant strain. Blots of EcoRI-digested DNAs of WT and $\Delta c b f 5$ strains, and $\Delta c b f 5$ strain transformed with pHCbf5 were probed with $\left[5^{\prime}-{ }^{32} \mathrm{P}\right]$-labeled HVCBF5-F primer. The predicted sizes of the hybridized fragments are indicated beside the panel. $(E)$ Growth curves of WT, $\Delta c b f 5$, and $\Delta c b f 5+$ pHCbf5 strains of $H$. volcanii are shown. $\mathrm{OD}_{600}$ was measured using a Bioscreen $\mathrm{C}$ apparatus. Each point is the mean of three independent cultures; error bars represent standard error. H26 and VDC2364 were used as WT and $\Delta c b f 5$ strains.

However, deletion of $c b f 5$ did not lead to any obvious phenotype when analyzing growth on solid medium at 20,30,37, 44 , and $50^{\circ} \mathrm{C}$ or with total salt concentrations ranging from $12 \%\left(1.812 \mathrm{M} \mathrm{NaCl}, 65.28 \mathrm{mM} \mathrm{MgCl}_{2}, 63 \mathrm{mM} \mathrm{MgSO}_{4}\right.$, and $41.64 \mathrm{mM} \mathrm{KCl})$ to $25 \%(3.775 \mathrm{M} \mathrm{NaCl}, 136 \mathrm{mM} \mathrm{MgCl}$, $131.25 \mathrm{mM} \mathrm{MgSO}_{4}$, and $86.75 \mathrm{mM} \mathrm{KCl}$ ) (compared to the standard YPC media with a final concentration of $18 \%$ salt; data not shown). It is presently unclear whether slower growth of the $c b f 5$-deleted strain is due to the absence of Cbf5 itself or due to the loss of Cbf5-catalyzed modifications.
The nonessentiality of $c b f 5$ in $H$. volcanii is in stark contrast to eukaryotes, where the gene is essential and point mutations lead to pleiotropic effects. Point mutations in yeast $c b f 5$ can abolish in vivo pseudouridylation of rRNA (Zebarjadian et al. 1999) and mutations in NAP57/dyskerin in mice decrease pseudouridylation of rRNA and assembly of box H/ACA RNP (Ruggero et al. 2003; Grozdanov et al. 2009). RNAi silencing of Trypanosoma brucei Cbf5 depleted box H/ACA RNAs, and caused defects in rRNA processing and trans-splicing (Barth et al. 2005). Partial loss-of-function 
mutations in the D. melanogaster ortholog minifly result in small size and developmental delay (Giordano et al. 1999). Mutations in the human ortholog dyskerin result in the disorder dyskeratosis congenita (Heiss et al. 1998; Knight et al. 1999; Mitchell et al. 1999). The number of $\Psi$ residues produced by Cbf5 is much larger in eukaryotes than in Archaea. Therefore, the essentiality of $c b f 5$ in complex eukaryotic systems may be due to the vital role of certain Cbf5-mediated $\Psi$ residues in biological processes, e.g., translation, pre-mRNA splicing, telomere maintenance, etc. Alternatively Cbf5 may have some other functions in addition to pseudouridylation in eukaryotes that may be essential. At least in yeast the essential nature of Cbf5 is not due to its pseudouridylation activity, because cells containing a mutant Cbf5 with the catalytic aspartate mutated to alanine lack $\Psi$ in their rRNA, but show a temperature-sensitive growth phenotype (Zebarjadian et al. 1999). Another possibility is a role of Cbf5 in maintaining essential H/ACA RNAs in eukaryotes. U17/E1/snR30 is a nonpseudouridylating H/ACA snoRNA that is essential for rRNA processing (and consequently cell growth) (Meier 2006). A Cbf5 depletion can destabilize this RNA. If the only activity of Cbf5 in "simpler" archaeal systems is to produce $\Psi$, then it might not be absolutely necessary under normal growth conditions.

\section{Cbf5 is needed for pseudouridylation of the large subunit rRNA residues of $\boldsymbol{H}$. volcanii}

$\Psi$ residues are found at four positions in the $23 \mathrm{~S}$ rRNA of Halobacterium salinarium (Halobacterium halobium) (Ofengand and Bakin 1997) corresponding to positions 1940, 1942, 2591, and 2605 in H. volcanii. The $23 S$ rRNA of Haloarcula marismortui contains only three $\Psi$ (Del Campo et al. 2005; Kirpekar et al. 2005). Position 2607 of $H$. marismortui (corresponding to $H$. volcanii 2591) contains an unmodified $U$. In $E$. coli the corresponding residues in the 23S rRNA are $\mathrm{m}^{3} \Psi 1915, \Psi 1917$, A2572, and U2586 (http://people.biochem.umass.edu/fournierlab/3dmodmap/ heneqlsu.php). Based on the correlation with $E$. coli and $H$. marismortui $23 \mathrm{~S}$ rRNAs, H. volcanii residues 1940 and 1942 are in the loop of helix 69 of domain IV, residue 2605 is between helix 90 and 93 of domain $\mathrm{V}$, and residue 2591 is in a bulge in the stem of helix 90 (http://people.biochem.umass. edu/fournierlab/3dmodmap/heneqlsu.php). We sought to determine which of the four $H$. volcanii positions contained $\Psi$, and which of these were Cbf5-mediated. Both CMCT and U-reaction based approaches were used to determine whether a $\Psi$ or an unmodified $U$ is present at each of these four positions in the WT strain. Furthermore, when $\Psi$ is present at a specific position, we determined whether it was replaced by an unmodified $U$ in the cbf5-deleted strain and, if so, whether it reverts to $\Psi$ in the complemented strain and is thus Cbf5-mediated.

Figure 2A,B shows that positions 1940 and 1942 of 23S rRNA contain $\Psi$ in the WT strain. However, the same positions contain unmodified $\mathrm{U}$ residues in the $\Delta c b f 5$ strain, which reverts back to $\Psi$ when $c b f 5$ is added back in trans. These results suggest that production of $\Psi$ at both positions 1940 and 1942 is Cbf5-mediated. Similar data presented in Figure 2C,D suggest that Cbf5 is also responsible for the formation of $\Psi$ at position 2605. Presence of $\Psi$ at these three positions is in agreement with the results of $H$. salinarium and $H$. marismortui (Ofengand and Bakin 1997; Del Campo et al. 2005; Kirpekar et al. 2005). These three $\Psi$ modifications were predicted to be catalyzed by Cbf5 in an RNA-guided manner (Grosjean et al. 2008). The results presented here confirm that Cbf5, at least, is critical in the production of these three $\Psi$ residues.

Analysis for the presence of $\Psi$ at position 2591 in 23S rRNA is less clear. Based on the data presented in Figure $2 \mathrm{E}, \mathrm{F}$, it appears that the formation of $\Psi 2591$ is Cbf5mediated as it is present only if the $c b f 5$ gene is present in cis or trans. We believe that conversion of $U$ to $\Psi$ at this position is not $100 \%$ for the following reasons. Neither $U$ nor $\Psi$ should produce a strong stop in untreated samples (see lanes 1 in Fig. 2A,C). However, presence of stops in lanes 1 of WT and $\Delta c b f 5+$ pHCbf5 (Fig. 2E) suggests that position 2591 contains a residue other than $U$ or $\Psi$, such as a secondary modification of $\Psi$ (see below). On the other hand lanes 2 (U-reaction) of the same strains should not show stops unless there is an unmodified $U$ (or an unknown modification of $U$ that behaves like an unmodified $U$ in aniline/hydrazine treatment) at position 2591. Similar incomplete conversion to $\Psi$ has also been observed in certain $H$. volcanii tRNAs (Gupta 1984) as well as in other RNAs (discussed in Grosjean 2005). Recently it has been shown that pseudouridylation of certain residues of S. cerevisiae U2 snRNA can be conditionally induced in response to nutrient deprivation and heat shock (Wu et al. 2011). At present we cannot be certain whether 23S rRNA with and without $\Psi 2591$ in our RNA preparations reflect a mixed population of rRNAs in each cell or a mixed population of cells, each containing only one type of rRNA. In the former case, it would raise questions as to whether each cell has two or more types of differentially modified ribosomes, each one representing different translation machinery or translating different groups of mRNAs.

Finally a secondary modification of $\Psi$ seems to occur at position 2591. Untreated RNAs of WT and $\Delta c b f 5+\mathrm{pHCbf5}$ strains, but not of $\Delta c b f 5$ strain, show a band (primerextension stop) at position 2591 (Fig. 2E, lanes 1). Primerextension stops with untreated RNAs do not appear to be due to the presence of a strong secondary structure in this region of the RNAs, as the untreated RNA of the $\Delta c b f 5$ strain does not show this stop, and $\Psi$ normally does not inhibit the extension. So far only four modifications of $\Psi$ have been identified, 1-methylpseudouridine $\left(\mathrm{m}^{1} \Psi\right)$ in Archaea, 1-methyl-3-(3-amino-3-carboxypropyl) pseudouridine $\left(\mathrm{m}^{1} \mathrm{acp}^{3} \Psi\right)$ in Eukarya, 3-methylpseudouridine $\left(\mathrm{m}^{3} \Psi\right)$ in Bacteria, and $2^{\prime}-O$-methylpseudouridine $(\Psi \mathrm{m})$ 
in both Archaea and Eukarya (http://rnamdb.cas.albany.edu/RNAmods/ and http:// modomics.genesilico.pl/modifications/). The first three are base modifications, whereas the last one is a ribose modification. These base modifications require $\mathrm{U}$ to $\Psi$ conversion, before production of secondarily modified $\Psi$. It is difficult to conclude at this point whether the secondary modification of $\Psi 2591$ in $H$. volcanii $23 \mathrm{~S}$ rRNA is one of the three known base modifications of $\Psi$ or is a new modification.

As mentioned above, $H$. salinarium also contains $\Psi(\Psi 2590)$ at the equivalent position to $H$. volcanii $\Psi 2591$ (Ofengand and Bakin 1997). It is possible that $H$. salinarium may also have this secondary modification of $\Psi$, since CMCT reactions alone may not be able to distinguish between $\Psi$ and certain modified $\Psi$. Again as mentioned above, $H$. marismortui is not reported to contain $\Psi$ at position 2607 (equivalent to $H$. volcanii 2591) (Del Campo et al. 2005; Kirpekar et al. 2005). However, Kirpekar's laboratory (Kirpekar et al. 2005) does see a medium strong stop at position 2607 of H. marismortui in their CMCT reactions but could not confirm the presence of $\Psi$ at this position by MALDI-MS study. It is possible that, like $H$. volcanii, $H$. marismortui may also contain a subpopulation of $23 \mathrm{~S}$ rRNAs that contain either a $\Psi$ or a secondarily modified $\Psi$ at their position 2607, while the rest contain unmodified $U$ at that position.

Position 2619 in $H$. marismortui 23S rRNA has been shown to contain 3-methyluridine $\left(\mathrm{m}^{3} \mathrm{U}\right)$ (Kirpekar et al. 2005), which inhibits primer extension. Residues at its equivalent positions in E. coli and human $23 \mathrm{~S}$ rRNAs are U2584 and $\mathrm{m}^{3} \mathrm{U} 4500$, respectively (http:// people.biochem.umass.edu/fournierlab/ $3 \mathrm{dmodmap} /$ heneqlsu.php). Lack of this $\mathrm{m}^{3} \mathrm{U}$ modification in $H$. salinarium has been shown to confer sparsomycin resistance (Lazaro et al. 1996; Kirpekar et al. 2005). Its equivalent position in $H$. volcanii is 2603, which shows strong primer-extension stops across all lanes in all strains (Fig. 2C,D). Taken together, this suggests that $H$. volcanii also has $\mathrm{m}^{3} \mathrm{U} 2603$ in its $23 \mathrm{~S}$ rRNA.
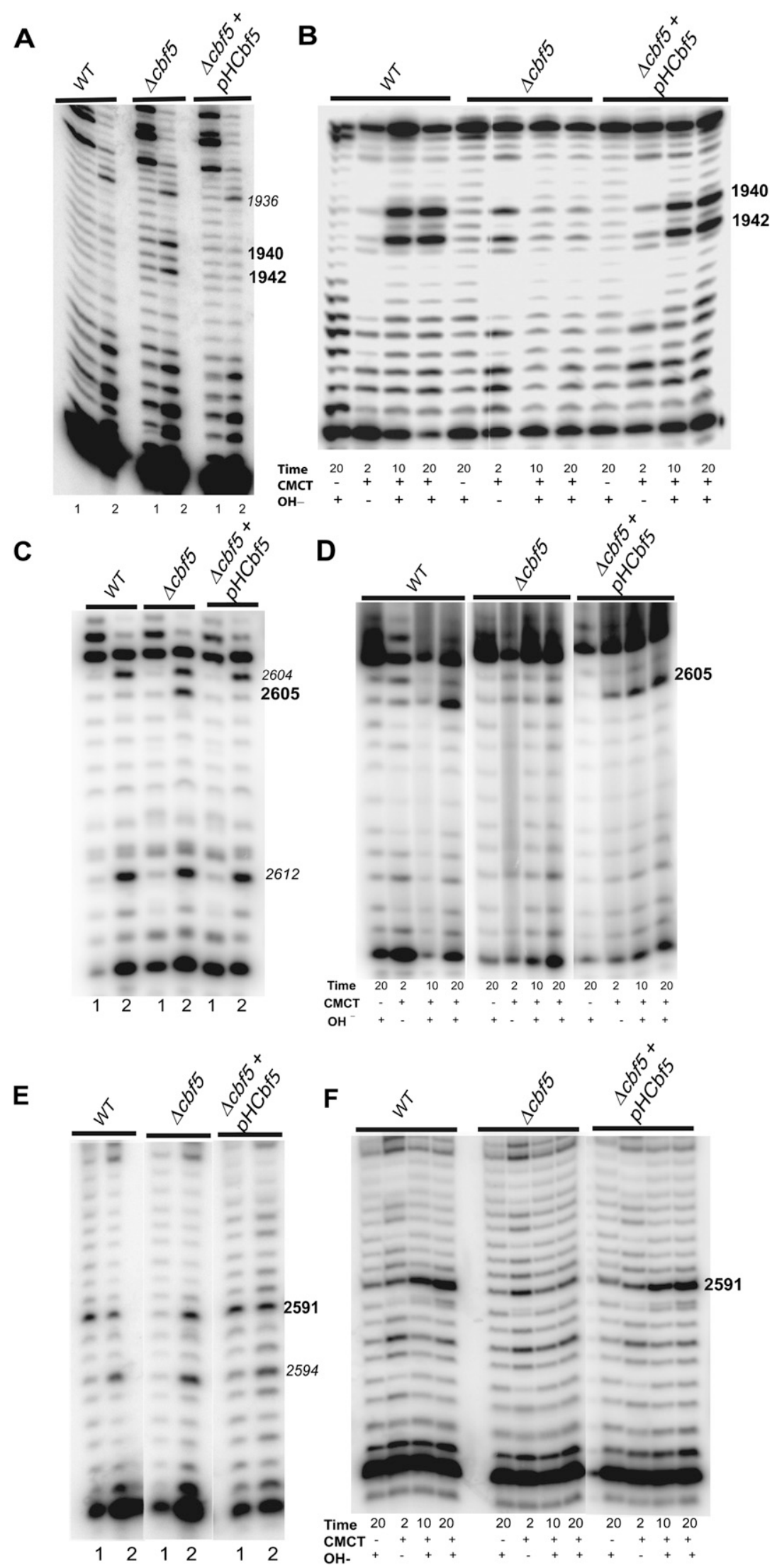

FIGURE 2. (Legend on next page) 


\section{$H$. volcanii tRNA $\Psi 55$ residues are produced even in the absence of Cbf5}

Positions of $\Psi$ residues in nearly all tRNAs of $H$. volcanii have been determined and compiled (Gupta 1984, 1986; Grosjean et al. 2008). However, determination of the presence or absence of these $\Psi$ in native tRNAs by primerextension-based methods is technically challenging. Strong secondary structure of tRNAs in general and presence of certain modified residues in single-stranded regions pause or halt reverse transcriptase reactions (Motorin et al. 2007). Furthermore, the presence of partial modifications at a given site (Gupta 1984) can make primer extension reactions difficult to interpret. Therefore, a combination of strategies was used to determine the effect of $c b f 5$-deletion in production of $\Psi \mathrm{s}$ at known positions of tRNAs.

Two panels in Figure 3A reflect nucleotide composition of total tRNA extracted from WT and $\Delta c b f 5$ cells. The amount of $\Psi$ appears to be the same in both strains. Most of the $\Psi$ in the tRNA population comes from $\Psi$ at positions 55 (in all tRNAs), and 13 and 39 (in several tRNAs) (Grosjean et al. 2008). Therefore, it appears that $\Psi$ modifications at these three positions are not Cbf5-mediated.

Cbf5 either alone or in association with other H/ACA RNP core proteins has been shown to produce $\Psi 55$ in a guide RNA-independent manner in vitro in full-size tRNAs or tRNA fragments containing T $\Psi \mathrm{C}$ stem-loop (Roovers et al. 2006; Gurha et al. 2007; Muller et al. 2007; Zhou et al. 2011). To test whether this reaction occurs in vivo, we analyzed $H$. volcanii $\mathrm{tRNA}^{\mathrm{Trp}}$. This tRNA contains only one $\Psi(\Psi 55)$ and one modified $\Psi\left(\mathrm{m}^{1} \Psi 54\right)$ (Gupta 1984$)$. The $\Psi / \mathrm{m}^{1} \Psi$ ratio of $\mathrm{tRNA}^{\mathrm{Tr} p}$ remains the same even after deletion of $c b f 5$, suggesting that Cbf5 is not the primary enzyme producing tRNA $\Psi 55$ (Fig. 3B) in vivo. As attempts to delete Pus10 were not successful (see below) the question whether $\Psi 55$ might be modified in vivo by Cbf5, in absence of active Pus10, remains open.

Cbf5 belongs to the TruB/Pus4 family of $\Psi$ synthases that produce tRNA $\Psi 55$ in Bacteria/Eukarya. Apparently archaeal Cbf5 protein, although specialized for RNA-guided activity, seems to have retained its capacity to produce tRNA
$\Psi 55$, though it does not seem to be its normal function. It is possible that there was a common ancestral mechanism for recognition of tRNA for $\Psi 55$ modification by TruB/ Pus4 and archaeal Cbf5. A similar example exists for archaeal and eukaryal tRNA splicing endonucleases (Fabbri et al. 1998; Fruscoloni et al. 2001), where the enzymes are homologous but have evolved to use different features of the pre-tRNAs to determine their cleavage sites (which are generally symmetric in Archaea and asymmetric in Eukarya). However, the eukaryal enzyme has retained the ability to use archaeal recognition signals. Alternatively, archaeal Cbf5 may produce $\Psi$ in rRNAs in vivo in both RNA-guided and guide RNA-independent manners, the latter reaction recognizing a structure somewhat similar to the TWC stem-loop of tRNA. Structures similar to this stem-loop are indeed present in rRNAs (Nagaswamy and Fox 2002; Krasilnikov and Mondragon 2003), and U2603 in a fragment of $P$. abyssi $23 \mathrm{~S}$ rRNA has been shown to be converted by Cbf5 along with other H/ACA core proteins in a guide RNAindependent manner (Muller et al. 2008). The sequence surrounding this U2603 can indeed be folded into a stem-

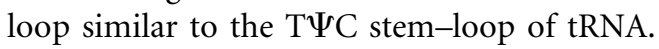

\section{Pus10, a tRNA $\Psi 55$ and $\Psi 54$ synthase, is essential in $H$. volcanii}

Another archaeal protein, Pus10, has been shown to produce $\Psi 54$ and $\Psi 55$ in tRNA in vitro and $\Psi 55$ in heterologous in vivo conditions (Roovers et al. 2006; Gurha and Gupta 2008). Despite several attempts, we failed to delete the $H$. volcanii pus10 homolog, HVO_1979, using our standard protocol. This led us to postulate that the gene might be essential. To address this, the gene was placed under control of the inducible $\mathrm{P}_{\text {tna }}$ promoter. A strain carrying the chromosomal HVO_1979 deletion could then be constructed in the presence of the gene in trans as described in the Methods section (Fig. 4). This strain required tryptophan for growth, hence providing strong evidence for pus10 essentiality in $H$. volcanii (Fig. 4). The in vitro data that showed Pus 10 can introduce $\Psi$ residues at positions 54 and 55 in tRNA combined with evidence presented above that $\Psi 55$ is present in tRNAs of cbf5-deleted strains suggest that Pus10 is primarily responsible for the production of $\Psi 55$ and $\Psi 54$ in cellular tRNAs.

The essentiality of pus10 was unexpected as genes responsible for the insertion of $\Psi 55$ in the other domains of life, at least truB and pus4, are dispensable in E. coli and yeast, respectively (Becker et al. 1997; Gutgsell et al. 2000). The strains lacking truB and pus 4 are viable and have unmodified U55 in the tRNAs. This suggests that the essential nature of Pus10 in $H$. volcanii may be 
A
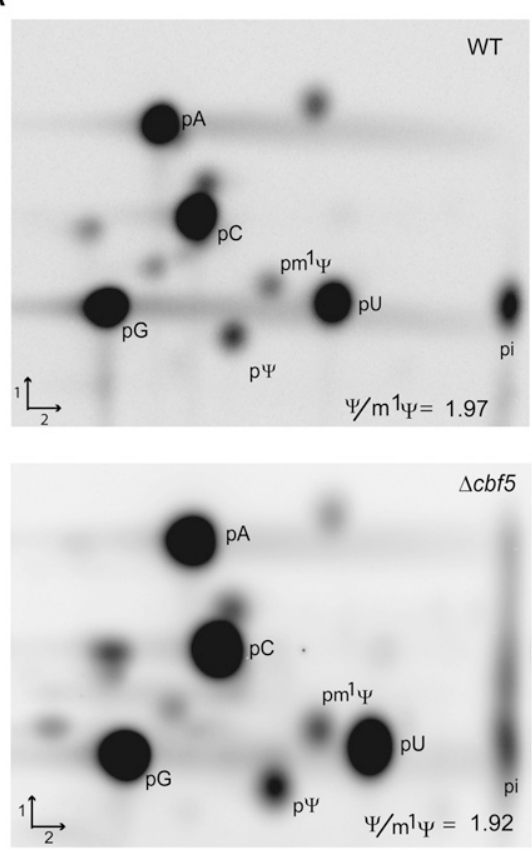

B
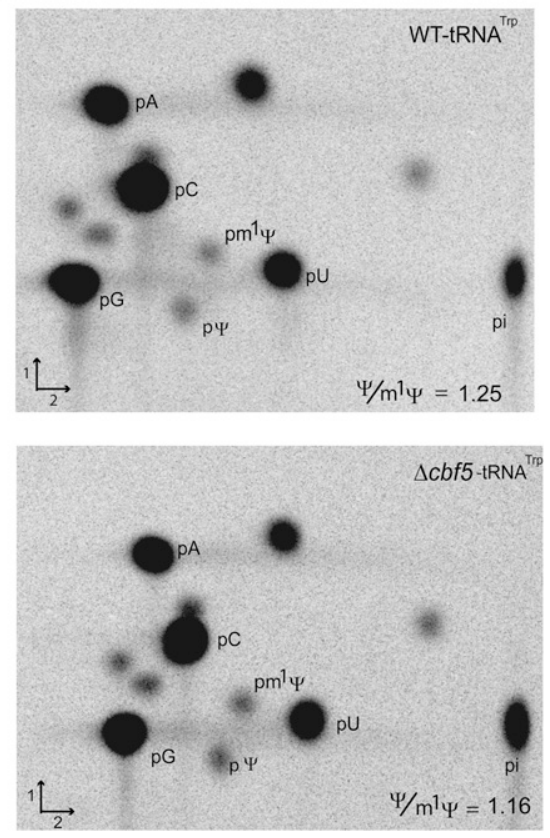

FIGURE 3. $c b f 5$ deletion does not significantly reduce the amount of $\Psi$ in $H$. volcanii total tRNAs and at tRNA position 55. Nuclease P1 digests of uniformly labeled tRNAs were resolved by thin layer chromatography. $\mathrm{pA}, \mathrm{pC}, \mathrm{pG}, \mathrm{pU}, \mathrm{p} \Psi$, and $\mathrm{pm}^{1} \Psi$ indicate $5^{\prime}$-phosphorylated A, C, $\mathrm{G}, \mathrm{U}, \Psi$, and $\mathrm{m}^{1} \Psi$, respectively. $(A, B)$ Digests of total tRNA and tRNA ${ }^{\mathrm{Trp}}$, respectively, from WT (upper panels) and $\Delta c b f 5$ strains (lower panels). Ratio of $\Psi$ and $\mathrm{m}^{1} \Psi$ is indicated in each panel.

either due to its role in tRNA $\Psi 54$ synthesis or in $\Psi$ production at a presently unidentified position in other cellular RNAs. Alternatively Pus10 may be essential because of a function not related to pseudouridylation such as a possible chaperone function during tRNA maturation or being part of a multiprotein complex having some nonpseudouridylation function. Furthermore, Pus10 might not be essential in other Archaea. The in vitro $\Psi 54$ activity of Pus10 from M. jannaschii is more robust than of Pus10 from $P$. furiosus, which may be a reflection of their in vivo functions (Gurha and Gupta 2008). Indeed, Thermococcales seem to have mostly 5 -methyluridine $\left(\mathrm{m}^{5} \mathrm{U}\right.$ or $\left.\mathrm{rT}\right)$ as 5-methyl-2-thiouridine $\left(\mathrm{m}^{5} \mathrm{~s}^{2} \mathrm{U}\right.$ or $\left.\mathrm{s}^{2} \mathrm{~T}\right)$ in tRNA and few $\Psi 54$ (or $\mathrm{m}^{1} \Psi 54$ ) (Edmonds et al. 1991; Kowalak et al. 1994; Constantinesco et al. 1999; Urbonavicius et al. 2008). If this were the case, then it would be interesting to test if pus10 is essential in Pyrococcus sp.

\section{Cbf5 is not needed for most of the tRNA $\Psi$ residues of $\boldsymbol{H}$. volcanii, but TruA/Pus3 homolog is needed for $\Psi 39$}

We determined the $\Psi$ status at certain other positions of tRNAs in Cbf5-deleted strains of $H$. volcanii, in addition to the $\Psi 55$ mentioned above, by primer extension following $\mathrm{U}$-specific and CMCT reactions with RNAs of WT and $\Delta c b f 5$ strains using elongator tRNA ${ }^{\text {Met }}$-specific primers (Fig. 5).
Both strains show the presence of $\Psi 13$ and $\Psi 22$ in tRNA $^{\text {Met }}$ (Fig. 5A,B), suggesting that neither the formation of $\Psi 13$ nor $\Psi 22$ are Cbf5-mediated. Probably $\Psi 13$ is produced by TruD/Pus7 because a homolog is present in $\mathrm{H}$. volcanii (Grosjean et al. 2008), and P. abyssi Pus7 can produce $\Psi 13$ in vitro (Muller et al. 2009).

Similar analysis using CMCT reactions suggests that $\Psi 39$ in elongator tRNA $^{\text {Met }}$ is also not Cbf5-mediated (Fig. $5 \mathrm{C}, \mathrm{D})$ thus is not guide RNA dependent, whereas 2'-O-methylation of $U$ at the same position 39 in tRNA $^{\text {Trp }}$ of $H$. volcanii is guide RNA dependent (Clouet d'Orval et al. 2001; Singh et al. 2004). Y39 in tRNAs of Bacteria and Eukarya is produced by TruA and Pus3, respectively. Therefore, we deleted the gene encoding their $H$. volcanii homolog, HVO_1852 (data not shown). Primer extension following U-specific and CMCT reactions using WT and $\triangle H V O \_1852$ strains (Fig. 5C,D) shows that indeed as for Bacteria and Eukarya the TruA/Pus3 homolog in $H$. volcanii catalyzes the formation of $\Psi 39$ in tRNA, further confirming that it is not Cbf5-mediated. Furthermore, these results show that pus3 in $H$. volcanii is not essential.

In addition to $\Psi$ at positions 13,39 , and 55 (and $\mathrm{m}^{1} \Psi 54$ ), $\Psi$ is also present at four other positions in $H$. volcanii tRNAs and only in one tRNA for each of these additional positions. These are $\Psi 22$ in elongator tRNA ${ }^{\mathrm{Met}}, \Psi 28$ in tRNA ${ }^{\text {Ile }}, \Psi 38$ in $\mathrm{tRNA}^{\text {Pro }}$, and $\Psi 52$ in tRNA ${ }^{\text {Lys }}$, the last three being only in the major isoacceptor for these amino acids (Gupta 1984; Grosjean et al. 2008). While we have demonstrated above that $\Psi 22$ is not Cbf5-mediated, we were unable to obtain clear evidence as to whether Cbf5 has any role in the production of $\Psi 28$. We did not attempt to determine $\Psi 38$ and $\Psi 52$ production in this analysis, because both of these show partial modification of tRNAs (Gupta 1984). The ratio of $U$ vs. $\Psi$ can vary from a tRNA preparation to another, which can affect the analysis of the data. However, based on the activities of E. coli TruA and S. cerevisiae Pus3 (Kammen et al. 1988; Nurse et al. 1995; Lecointe et al. 2002), we can assume that $\Psi 38$ is also produced by their homolog in $H$. volcanii. At present it is difficult to predict any $\Psi$ synthase for the other three positions $(22,28$, and 52$)$ with any certainty.

\section{cbf5 deletion reduces the amounts of guide box H/ACA RNAs in $H$. volcanii}

Two box H/ACA guide RNAs have been proposed for production of $\Psi$ in $H$. volcanii 23 rRNA: one for U2605 


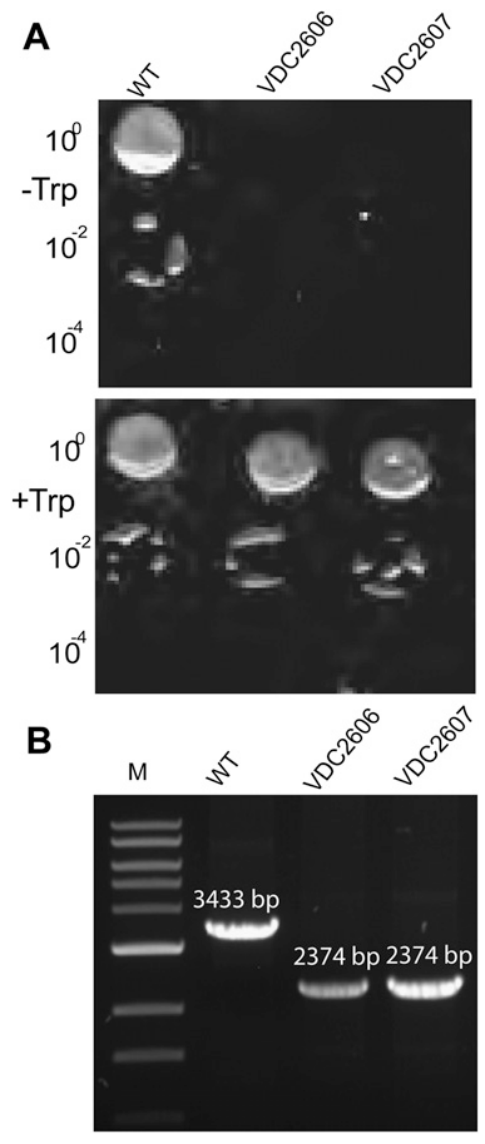

FIGURE 4. pus10 is essential in H. volcanii. pus10 (HVO_1979) could only be deleted from the chromosome when expressed in trans. $(A)$ $\mathrm{H} 26$ (WT) and two independent isolates VDC2606 and VDC2607 ( $\Delta H V O \_1979$ with plasmid-borne copy of $H V O \_1979$ under $\mathrm{P}_{t n a}$ control) were serially diluted from $10^{0}$ to $10^{-4}$ and spotted onto Hv-Min media plates, plus and minus $500 \mu \mathrm{M}$ tryptophan. Significant growth of the mutant is only observed in the presence of tryptophan. (B) Deletion of the chromosomal copy of HVO_1979 was further verified by PCR using primers Pus10_Ext_Fwd and Pus10_Ext_Rev. Predicted sizes of the amplicon are indicated above each band.

and another one for both U1940 and U1942 (Grosjean et al. 2008). Both of these RNAs are present in the cell as shown by Northern hybridizations of WT RNA using appropriate probes (Fig. 6B). Interestingly, signals for the probes were greatly reduced in the $\Delta c b f 5$ strain, but the signals return to WT levels when the mutant strain is supplemented with a plasmid-borne copy of cbf5. This suggests that, in the absence of Cbf5, H/ACA RNAs are destabilized and get degraded. This would be expected if these RNAs normally formed H/ACA RNP complexes with Cbf5 and other proteins and were thereafter protected against cellular RNA nucleases. Similar situations are observed in yeast, where genetic depletion of Cbf5 leads to depletion of all box H/ACA snoRNAs (Lafontaine et al. 1998) and in T. brucei, where RNAi-mediated depletion of Cbf5 destabilized box H/ACA snoRNAs (Barth et al. 2005). Our results in Figures
2A-D and 6B together suggest that $\Psi 1940,1942$, and 2605 in $23 \mathrm{~S}$ rRNA are produced by H/ACA RNPs. This is confirmed for the position 2605 by our in vitro pseudouridylation assays using appropriate guide RNAs, and a 23S rRNA fragment containing U2605 and recombinant M. jannaschii proteins (M Majumder and R Gupta, unpubl.).

\section{A double stem-loop box H/ACA RNA in $H$. volcanii}

Both probes used for Northern analyses seemed to hybridize to one RNA of $\sim 200$ bases (Fig. 6B). The two sRNA sequences are located near each other in the $H$. volcanii genome (http://archaea.ucsc.edu) and are separated by a 59-base spacer region between the two stem-loops. Therefore, we used the same two probes to determine the $5^{\prime}$ ends of the two RNAs. As seen in Figure 6C,D, both RNAs have the same $5^{\prime}$ end, suggesting that both RNAs are part of the same molecule. Reduced signals in the $\Delta c b f 5$ strain (Fig. 6C,D) again confirm the reduced level of this box H/ACA RNA in the mutant strain and the recovery to original levels when the strain is supplemented with a plasmid-borne copy of $c b f 5$. Archaeal H/ACA RNAs mostly have either one or three stem-loops, though two stem-loops have also been observed, albeit rarely (Dennis and Omer 2005; Muller et al. 2008). This $H$. volcanii RNA is a rare case of archaeal H/ACA RNA containing two stem-loops. Normally spacer regions between the stem-loops of archaeal H/ACA RNAs are very short (Grosjean et al. 2008; Muller et al. 2008). However, this double stem-loop RNA has a spacer of 59 bases (or 56 bases excluding ACA of the stem-loop on the 5 ' side). The spacer length between homologs of these two stem-loops among haloarchaea varies from 21 to 142 bases, but other Archaea have smaller spacers from 0 to 5 bases (Grosjean et al. 2008). This spacer of $H$. volcanii potentially can form a pseudoknot structure (inset in Fig. 6A). Interestingly, this spacer of all haloarchaeal species can also be folded into a pseudoknot structure (data not shown). Generally pseudoknots have some kind of regulatory role but it is not yet known if this structure between the two $\mathrm{H} / \mathrm{ACA}$ RNAs forms in vivo and whether it has any role there.

\section{CONCLUSIONS}

In conclusion, we present here the analysis and confirmation of several proteins previously predicted to be involved in pseudouridylation of ribonucleic acids in $H$. volcanii. We demonstrate that Cbf5 is responsible for making $\Psi$ at multiple positions of the large subunit of rRNA. Contrary to suggestions made by previous in vitro based assays Cbf5 does not appear to be involved in tRNA modification. Furthermore, while essential in yeast, $c b f 5$ is dispensable in $H$. volcanii, although its deletion does result in a slight growth defect. However, another protein suspected to be involved in pseudouridylation of at least U55 of tRNAs, 
A

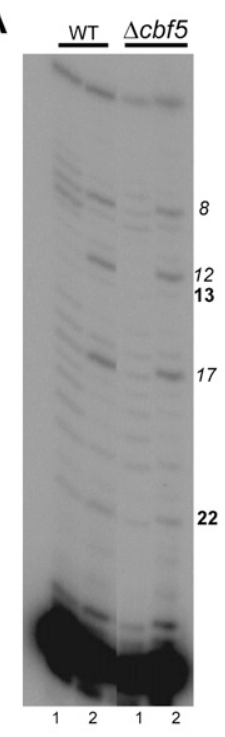

C

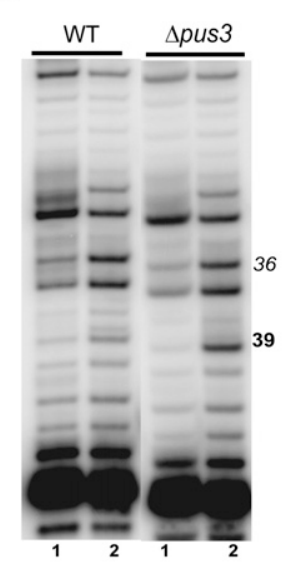

B

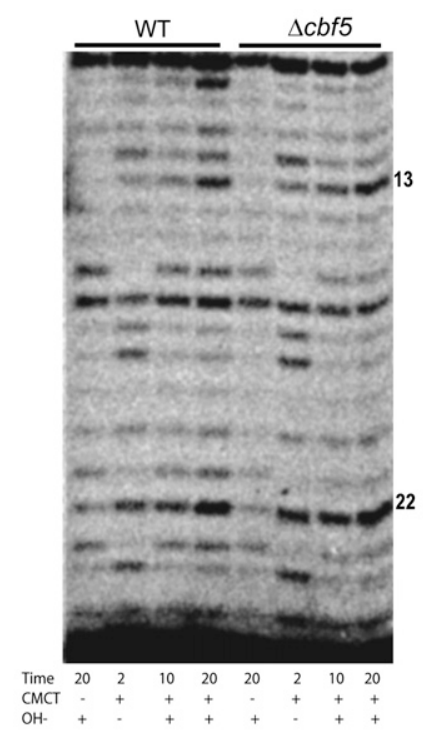

D
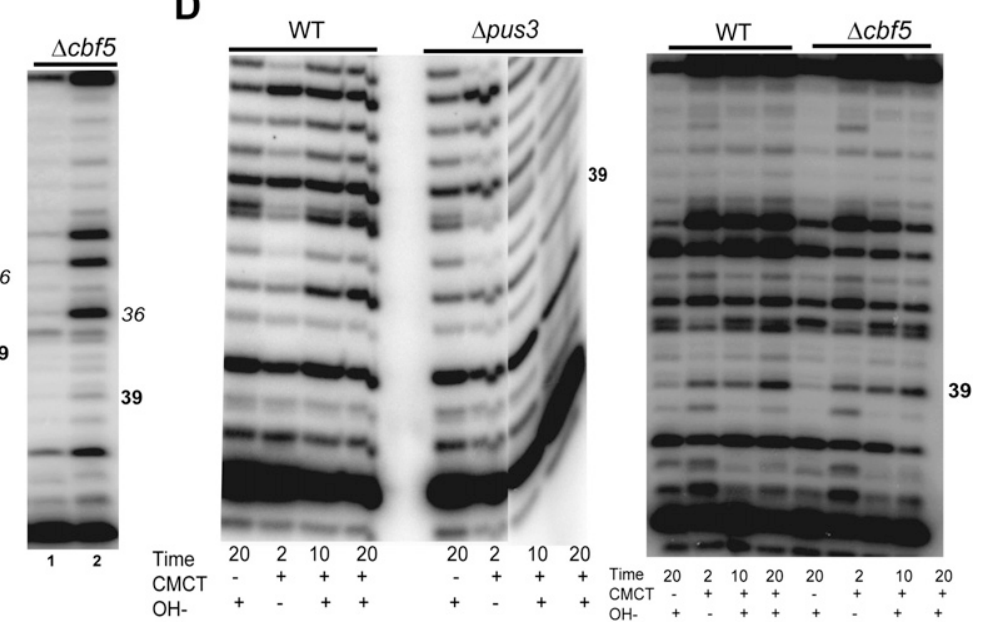

FIGURE 5. $H$. volcanii tRNA $\Psi 13, \Psi 22$, and $\Psi 39$ are not Cbf5-mediated and $\Psi 39$ is TruA/Pus3-mediated. (A) U-specific analyses to determine the modification status of U13 and U22 of elongator tRNA ${ }^{\text {Met }}$ were done using primer HVMETCR2 and total tRNAs of WT and $\Delta c b f 5$ strains. (Lanes 1,2) Primer extensions without and with U-specific reactions, respectively. Positions of certain Us and $\Psi 13$ and $\Psi 22$ in tRNA are indicated on the side. $(B)$ CMCT-primer extension analyses to determine the modification status of U13 and U22 of tRNA ${ }^{\text {Met }}$ were done using primer HVMETCR2 and total tRNAs of WT and $\Delta c b f 5$ strains. Total tRNAs were treated with $(+)$ or without $(-)$ CMCT for the indicated time (in minutes), followed by alkali $(\mathrm{OH}-)$ treatment $(+)$ or no treatment $(-)$. Positions of $\Psi 13$ and $\Psi 22$ are indicated on the side. (C,D) Analysis similar to those in $A$ and $B$, respectively, using primer VM5/6R, to determine the modification status of U39 of tRNA ${ }^{\text {Met }}$ in WT (H26), $\Delta p u s 3$ (VDC2465), and $\Delta c b f 5$ (VDC2364) strains.

Pus10, is necessary for viability. Finally we demonstrate that HVO_1852, the TruA homolog, is responsible for $\Psi 39$ in tRNA.

It is important to note that the results reported here might be specific to halophilic Archaea. Compared to E. coli or yeast, $H$. volcanii clearly contains a lower number of RNA modifications (both in tRNA and rRNA) and comparative genomics analysis suggests the number of RNA modifications in certain halophilic Archaea could be reduced even more. Indeed, as far as tRNAs are concerned, $H$. volcanii has already lost the tyw1 signature gene for the imG-14 modification (Waas et al. 2005) that is present in
H. salinarium (de Crécy-Lagard et al. 2010). Haloquadratum walsbyi, which lives in an environment with a much more stable salinity level than $H$. volcanii (Burns et al. 2007), has lost not only the tyw1 gene like $H$. volcanii but also the $\operatorname{tgt} A$ gene involved in the formation of archaeosine (Watanabe et al. 1997) and the gene encoding COG 1444 that has been shown to be involved in $\mathrm{ac}^{4} \mathrm{C}$ formation (El Yacoubi et al. 2009). A possibility is that high salt concentration can replace specific modifications in these organisms (discussed in Grosjean et al. 2008). It is therefore crucial to repeat the experiments reported here with nonhalophilic Archaea before any generalization is made. 
A

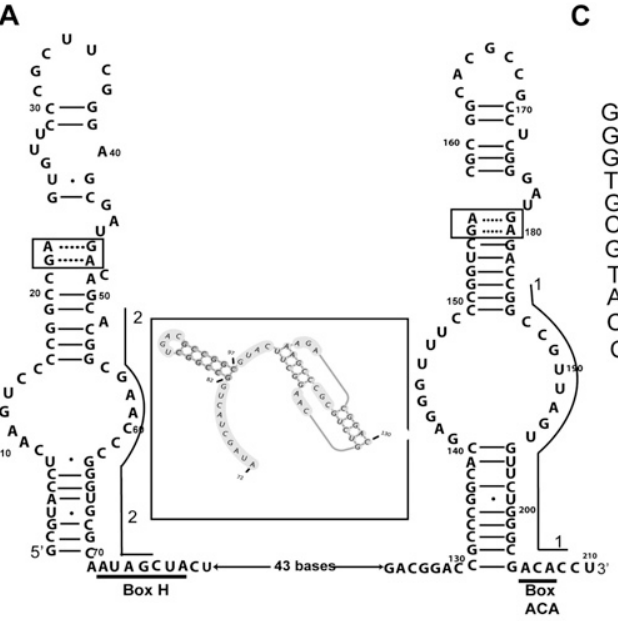

C

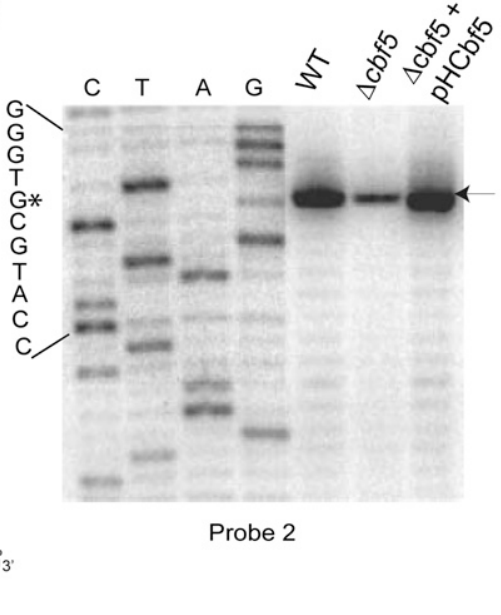

B

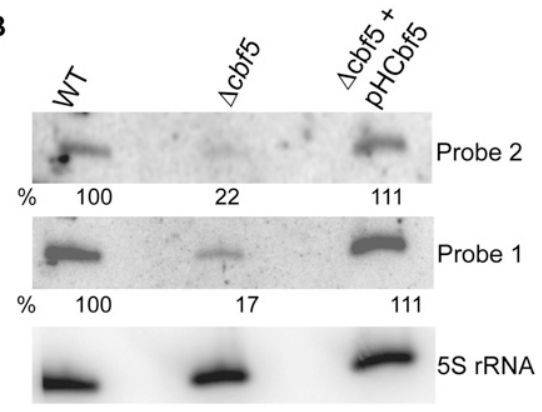

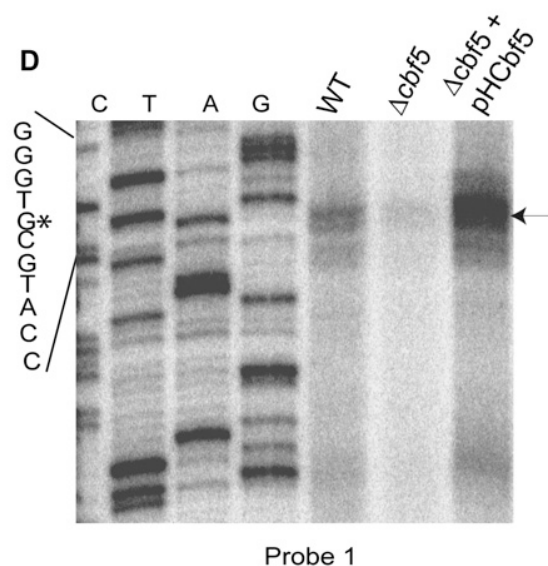

Probe 1

FIGURE 6. Levels of a double stem-loop box H/ACA guide RNA are reduced in the absence of Cbf5. (A) Primary sequence and predicted secondary structures of two H/ACA guide RNAs proposed (Grosjean et al. 2008) to be responsible for guiding pseudouridylation of U2605 and U1940/U1942 of $H$. volcanii $23 S$ rRNA. The 59-base region that separates the two RNAs in the genome can potentially form a pseudoknot (inset). Pseudoknot is drawn according to pknotsRG-mfe (http://bibiserv.techfak.uni-bielefeld.de/pknotsrg/). Conserved box $\mathrm{H}$ and box ACA are underlined. G•A pairs of K-turns are boxed. Positions for probe 1 (HV1940/42HAR) and probe 2 (HV2605HAR) are indicated by lines along the sequences. (B) Northern blot analysis of total RNA isolated from WT and $\Delta c b f 5$ strains, and $\Delta c b f 5$ transformed with pHCbf5. Blot was hybridized using probes 1 and 2 (shown in $A$ ). Both probes hybridized to an $\sim 200$-base RNA. 5S rRNA-specific probe was used as a loading control. Quantity of RNA in each hybridized band is indicated. $(C)$ Primer extension and sequencing reactions using probe 2 to determine $5^{\prime}$ ends of the RNAs. Equal amounts of total RNAs from WT and $\Delta c b f 5$ strains and $\Delta c b f 5$ transformed with pHCbf5 were used in the reactions. Sequence in the region of primer stop is indicated on the side. Asterisked G indicates the $5^{\prime}$ end of the RNA. $(D)$ Reactions similar to $C$, using probe 1 .

\section{MATERIALS AND METHODS}

\section{Strains, plasmids, oligonucleotides, media, and transformation procedures}

All strains, plasmids, and oligonucleotides used in this study are detailed in Supplemental Tables S1, S2, and S3, respectively. $H$. volcanii $\mathrm{H} 26$ was received from Julie Maupin-Furlow as well as from Thorsten Allers. Plasmids pJAM202 (Kaczowka and Maupin-Furlow 2003) and pMDS132, a derivative of pMLH32 (Holmes and DyallSmith 2000), were gifts from Julie Maupin-Furlow and Michael Dyall-Smith, respectively. H26 and VDC2364 (prepared in this work) were used in this study as WT and $\Delta c b f 5$ strains of $H$. volcanii. E. coli was routinely grown in $\mathrm{LB}$ (Fisher) or LB agar (Fisher) at $37^{\circ} \mathrm{C}$, supplemented when required with ampicillin (100 $\mu \mathrm{g} / \mathrm{mL}$ ), isopropyl $\beta$-D-1-thiogalactopyranoside $(0.2 \mathrm{mM})$, and bromo-chloroindolyl-galactopyranoside $(40 \mu \mathrm{g} / \mathrm{mL})$. $H$. volcanii cells were routinely grown at $42^{\circ} \mathrm{C}-44^{\circ} \mathrm{C}$ (unless specified) in $\mathrm{Hv}$-YPC, $\mathrm{Hv}-\mathrm{CA}$, and Hv-Min as described in the HaloHandbook (http://www.haloarchaea.com/ resources/halohandbook/Halohandbook_ 2008_v7.pdf) or in a standard medium as described previously (Gupta 1984). Transformations of $E$. coli were performed by standard protocols (Sambrook and Russell 2001) or as described by the manufacturer (Invitrogen). Transformation of $H$. volcanii was performed as described in the HaloHandbook using the "standard PEG-mediated transformation of haloarchaea" protocol. Briefly, spheroplasts were made by adding $100 \mu \mathrm{L} 0.5 \mathrm{M}$ EDTA ( $\mathrm{pH} 8.0)$ to $1 \mathrm{~mL}$ concentrated cells, incubating at room temperature for $10 \mathrm{~min}$; $2 \mu \mathrm{g}$ plasmid DNA was then added to $100 \mu \mathrm{L}$ spheroplasts and incubated for $5 \mathrm{~min}$; $100 \mu \mathrm{L} 60 \%$ (v/v) PEG600 was added and mixed gently, and the mixture incubated at room temperature for $30 \mathrm{~min}$. Cells were recovered by adding recovery solution, as described in the HaloHandbook, and incubated for $4 \mathrm{~h}$ at $42^{\circ} \mathrm{C}-44^{\circ} \mathrm{C}$ before plating onto the appropriate media. Phenotypes (growth rate, and growth at different salt concentrations and temperature) were tested as described previously (Blaby et al. 2010).

\section{Deletion strain and plasmid construction}

Plasmids to delete $H$. volcanii genes were constructed as described previously (Blaby et al. 2010). Briefly, regions of $\sim 600$ bp upstream of and downstream from the gene to be deleted, along with a small portion of the gene at both ends to avoid affecting neighboring genes, were PCR-amplified from $H$. volcanii genomic DNA and recombined between the XhoI and EcoRI sites of pTA131 using InFusion (Clontech); $0.2 \mu \mathrm{L}$ of the reaction mixture was transformed to TOP10 chemically competent cells (Invitrogen) and plated onto LB plus ampicillin (100 $\mu \mathrm{g} / \mathrm{mL})$, isopropyl $\beta$-D-1-thiogalactopyranoside $(0.2 \mathrm{mM})$, and bromo-chloro-indolyl-galactopyranoside $(40 \mu \mathrm{g} / \mathrm{mL})$. Clones were screened by PCR using M13 primers (which anneal on either side of the multiple cloning site of pTA131) using 5' Master Mix (Eppendorf) as per the directions, and confirmed by sequencing using the UF Sequencing facility.

The plasmid generated to disrupt HVO_2493 (pIKB219) was constructed as described above using oligonucleotide pairs HVO2493_ N_IfKO_Fwd, HVO2493_N_IfKO_Rev, HVO2493_C_IfKO_Fwd, 
and HVO2493_C_IfKO_Rev. The plasmid constructed to delete HVO_1979 (pIKB180) was made using oligonucleotides HVO_ 1979_N_IfKO_Fwd, HVO_1979_N_IfKO_Rev, HVO_1979_C_IfKO_ Fwd, and HVO_1979_C_IfKO_Rev. The plasmid used to delete HVO_1852 (pIKB199) was made using HVO_1852_N_IfKO_Fwd, HVO_1852_N_IfKO_Rev, HVO_1852_C_IfKO_Fwd, and HVO_ 1852_C_IfKO_Rev.

Once obtained, deletion plasmids were passed through a dam $^{-}$ E. coli (INV110; Invitrogen), transformed into $H$. volcanii $\mathrm{H} 26$ (or derivatives) as described above. Deletion of the targeted locus was selected in a two-step process as described previously (Allers et al. 2004). Briefly, insertion of the deletion plasmid by a single crossover event was selected for by ability to grow on Hv-CA (i.e., in the absence of uracil). Subsequent excision of the integrated plasmid and target gene by a second recombination event was selected for by plating onto $\mathrm{Hv}-\mathrm{CA}$ supplemented with uracil $(10 \mu \mathrm{g} / \mathrm{mL})$ and 5-fluoroorotic acid (5-FOA; $50 \mu \mathrm{g} / \mathrm{mL}$ ). Gene deletion candidates were screened using a PCR-based method as follows. One pair of primers (denoted by the suffix _Ext_Fwd and _Ext_Rev) was designed to anneal within the flanking regions of the gene to be deleted, and the amplicon compared to WT and predicted size. To confirm loss of the gene, a second pair of primers (suffixed _Int_Fwd and_Int_Rev) was designed to anneal within the gene to be deleted. Gene deletions were verified by amplification of the fragment in the WT, but inability in mutant strains.

\section{Other plasmid and strain constructions}

pHCbf5 was generated by replacing $\sim 420$ bp NdeI-EcoRI fragment of pMDS132 with an $\sim 890$ bp PCR fragment produced by amplifying HVO_2493 using HVCBF5ND-F2 and HVCBF5-R2 primers. An amplified gene contains six His codons just before the stop codon. The reaction mixture was used to transform $\mathrm{DH} 5 \alpha$ cells. Plasmids were verified by PCR, restriction digestion, and sequencing, and then passed through E. coli GM2929 and transformed into $H$. volcanii strain VDC2364 ( $\Delta c b f 5$ strain). Transformants were selected for by plating onto Hv-YPC containing novobiocin $(0.8 \mu \mathrm{g} / \mathrm{mL})$.

A fragment from the $H$. volcanii genome containing the $\mathrm{P}_{t n a}$ promoter was PCR-amplified using primers Ptna_5 and rev-Ptna, and inserted between the $B l p \mathrm{I}$ and $\mathrm{XbaI}$ sites of pTA131, to generate pPT002. pus10 was subsequently PCR-amplified using primers Pus10_tna_Nde_Fwd and Pus10_tna_Rev from $H$. volcanii genomic DNA and inserted between the NdeI and EcoRV sites of pPT002 to generate pIKB487. Subsequent deletion of the chromosomal copy of pus10 was performed as described by Allers and colleagues (Allers et al. 2004; Large et al. 2007) using pIKB180 to disrupt the gene in the strain transformed with pIKB487.

\section{Mapping the sites of $\Psi$ in RNAs}

Presence of $\Psi$ in RNA was analyzed by the 1-cyclohexyl-3-(2morpholinoethyl) carbodiimide metho-p-toluenesulfonate (CMCT) modification technique (Ofengand et al. 2001a; Motorin et al. 2007). Briefly, $20 \mu \mathrm{g}$ total RNA or $10 \mu \mathrm{g}$ gel-purified tRNA was treated with CMCT for 2,10 , and $20 \mathrm{~min}$ each at $37^{\circ} \mathrm{C}$, while an untreated sample was simply incubated at $37^{\circ} \mathrm{C}$ for $20 \mathrm{~min}$ as control. After precipitation of the RNA, alkali treatment was done for $3 \mathrm{~h}$ at $37^{\circ} \mathrm{C}$ for all samples except for the ones treated with CMCT for $2 \mathrm{~min}$. Again after precipitation, the RNA was used for primer extension using $\left[5^{\prime}-{ }^{32} \mathrm{P}\right]$-labeled primers that hybridized close to and on the $3^{\prime}$ side of the position to be mapped for $\Psi$. M-MLV reverse transcriptase (Promega) was used for primer extension according to the manufacturer's instructions. The extension stops at one residue before the CMCT modified $\Psi$. A dark band in CMCT followed by alkali treatment lanes, with an increased intensity in the 20 min treatment lane, indicates the presence of $\Psi$ at that position. The position of the band in the gel that corresponds to $\Psi$ is determined by its distance from the end of the primer and sometimes the presence of darker bands for $\mathrm{U}$ and $\mathrm{G}$ in 2 min CMCT but no alkali treatment lane, and correlation with the known sequence of the RNA.

U-specific sequencing reactions (Peattie 1979; Gupta 1984) followed by primer extension were used to determine the positions of $U$ (absence of $\Psi$ ) in the RNAs. Briefly, $20 \mu \mathrm{g}$ total RNA or $10 \mu \mathrm{g}$ gel-purified tRNA was treated with $50 \%$ hydrazine for $20 \mathrm{~min}$ on ice and precipitated. The RNA was then treated with acidified aniline at $60^{\circ} \mathrm{C}$ for $20 \mathrm{~min}$. Precipitated RNA was then used for primer extension as above for the CMCT reaction. Here also the position of the primer extension band in the gel is one residue before the expected U. A dark band in the hydrazineaniline treated lane but not in the untreated lane indicates the presence of an unmodified $U$ at that position. A correlation between the position of the dark band in the gel relative to the end of the primer and positions of unmodified Us in the known sequence of the RNA determines the position of $\Psi$.

\section{Quantitation of $\Psi$ residues in tRNAs}

Uniformly labeled total tRNA was prepared as described before (Gupta 1984; Joardar et al. 2008). When needed, uniformly labeled tRNA ${ }^{\text {Trp }}$ was isolated from this total tRNA according to previously published procedures (Joardar et al. 2008). Labeled tRNAs were digested with nuclease P1 and digests were resolved by two-dimensional thin-layer chromatography on cellulose plates (EM Science) using isobutyric acid/0.5 N NH${ }_{4} \mathrm{OH}(5: 3, \mathrm{v} / \mathrm{v})$ in the first dimension and isopropanol/ $\mathrm{HCl} / \mathrm{H}_{2} \mathrm{O}(70: 15: 15, \mathrm{v} / \mathrm{v} / \mathrm{v})$ in the second dimension (Gupta 1984). Radioactivity in the plates was revealed and quantified by phosphorimaging. The amount of $\Psi$ per tRNA was determined by the ratio of radioactivities in $\Psi$ vs. $\mathrm{m}^{1} \Psi$ nucleotide spots. The reasons for using $\mathrm{m}^{1} \Psi$ spot for comparison are because nearly all $H$. volcanii tRNAs have one $\mathrm{m}^{1} \Psi$ residue per tRNA (Gupta 1984, 1986), $\Psi$ for this $\mathrm{m}^{1} \Psi$ is produced by Pus10 (Gurha and Gupta 2008) not by Cbf5, and this nucleotide is well separated in our chromatography system.

\section{Southern and Northern hybridizations, and mapping the $5^{\prime}$ ends of guide RNAs}

The genomic deletion of $c b f 5$ was checked by Southern hybridization of EcoRI-digests of DNA using standard procedures (Sambrook and Russell 2001). The blots were hybridized with $\left[5^{\prime}-{ }^{32} \mathrm{P}\right]$-labeled HVCBF5-F primer. For Northern analyses, total RNA was isolated from the cells using TRI reagent (Molecular Research Center, Inc). The RNA was separated by a $6 \%$ denaturing PAGE. The blots were prepared and hybridized to $\left[5^{\prime}-{ }^{32} \mathrm{P}\right]$-labeled probes according to standard procedures (Sambrook and Russell 2001). The blot was stripped (incubated in $10 \mathrm{mM}$ Tris- $\mathrm{Cl} \mathrm{pH} \mathrm{7.4,0.2 \%} \mathrm{SDS} \mathrm{at} 70^{\circ} \mathrm{C}$ for $2 \mathrm{~h}$ ) after hybridization for use with a second probe. Radioactivity was detected and quantified (when needed) by phosphorimaging. The amount of H/ACA RNA in Northern blots was quantitated by using 
a band for 5S rRNA in each lane as a loading control and normalizing each H/ACA RNA band in that lane against these controls. The amount of RNA in WT is considered $100 \%$ in each case. To determine $5^{\prime}$ ends of the guide RNAs the primers used in Northern analyses were $5^{\prime}{ }_{-}{ }^{32} \mathrm{P}$ labeled and used with total RNA for extension reactions.

\section{SUPPLEMENTAL MATERIAL}

Supplemental material is available for this article.

\section{ACKNOWLEDGMENTS}

H. volcanii $\mathrm{H} 26$ was received from Julie Maupin-Furlow (University of Florida) as well as from Thorsten Allers (University of Nottingham, UK). Plasmids pJAM202 and pMDS132 were gifts from Julie Maupin-Furlow and Michael Dyall-Smith (Charles Sturt University, Australia), respectively. We thank Wayne Decatur for the help in correlating the positions of $\Psi$ in $H$. volcanii with those of other haloarchaea and E. coli. We thank Patrick Thiaville for the construction of pTA002. H.G. holds a CNRS position of Emeritus Scientist at the University Paris-South in Orsay-France. This work was funded in part by National Science Foundation grant number MCB-05169448 to V.d.C.-L. and by NIH grant number GM055945 to R.G.

Received March 9, 2011; accepted April 15, 2011.

\section{REFERENCES}

Allers T, Ngo HP, Mevarech M, Lloyd RG. 2004. Development of additional selectable markers for the halophilic archaeon Haloferax volcanii based on the leuB and trpA genes. Appl Environ Microbiol 70: $943-953$.

Arnez JG, Steitz TA. 1994. Crystal structure of unmodified tRNA(Gln) complexed with glutaminyl-tRNA synthetase and ATP suggests a possible role for pseudo-uridines in stabilization of RNA structure. Biochemistry 33: 7560-7567.

Auffinger P, Westhof E. 1997. RNA hydration: Three nanoseconds of multiple molecular dynamics simulations of the solvated tRNA(Asp) anticodon hairpin. J Mol Biol 269: 326-341.

Baker DL, Youssef OA, Chastkofsky MI, Dy DA, Terns RM, Terns MP. 2005. RNA-guided RNA modification: Functional organization of the archaeal H/ACA RNP. Genes Dev 19: 1238-1248.

Barth S, Hury A, Liang XH, Michaeli S. 2005. Elucidating the role of H/ACA-like RNAs in trans-splicing and rRNA processing via RNA interference silencing of the Trypanosoma brucei CBF5 pseudouridine synthase. J Biol Chem 280: 34558-34568.

Baudin-Baillieu A, Fabret C, Liang XH, Piekna-Przybylska D, Fournier MJ, Rousset JP. 2009. Nucleotide modifications in three functionally important regions of the Saccharomyces cerevisiae ribosome affect translation accuracy. Nucleic Acids Res 37: 7665-7677.

Becker HF, Motorin Y, Planta RJ, Grosjean H. 1997. The yeast gene YNL292w encodes a pseudouridine synthase (Pus4) catalyzing the formation of $\Psi_{55}$ in both mitochondrial and cytoplasmic tRNAs. Nucleic Acids Res 25: 4493-4499.

Blaby IK, Phillips G, Blaby-Haas CE, Gulig KS, El Yacoubi B, de Crécy-Lagard V. 2010. Towards a systems approach in the genetic analysis of archaea: Accelerating mutant construction and phenotypic analysis in Haloferax volcanii. Archaea 2010: 426239. doi: $10.1155 / 2010 / 426239$

Burns DG, Janssen PH, Itoh T, Kamekura M, Li Z, Jensen G, Rodriguez-Valera F, Bolhuis H, Dyall-Smith ML. 2007. Haloquadratum walsbyi gen. nov., sp. nov., the square haloarchaeon of
Walsby, isolated from saltern crystallizers in Australia and Spain. Int J Syst Evol Microbiol 57: 387-392.

Cantara WA, Crain PF, Rozenski J, McCloskey JA, Harris KA, Zhang X, Vendeix FA, Fabris D, Agris PF. 2011. The RNA Modification Database, RNAMDB: 2011 update. Nucleic Acids Res 39: D195D201.

Charette M, Gray MW. 2000. Pseudouridine in RNA: What, where, how, and why. IUBMB Life 49: 341-351.

Charpentier B, Muller S, Branlant C. 2005. Reconstitution of archaeal H/ACA small ribonucleoprotein complexes active in pseudouridylation. Nucleic Acids Res 33: 3133-3144.

Clouet d'Orval B, Bortolin ML, Gaspin C, Bachellerie JP. 2001. Box C/D RNA guides for the ribose methylation of archaeal tRNAs. The tRNA-Trp intron guides the formation of two ribose-methylated nucleosides in the mature tRNA-Trp. Nucleic Acids Res 29: 45184529.

Constantinesco F, Motorin Y, Grosjean H. 1999. Transfer RNA modification enzymes from Pyrococcus furiosus: Detection of the enzymatic activities in vitro. Nucleic Acids Res 27: 1308-1315.

Davis DR. 1995. Stabilization of RNA stacking by pseudouridine. Nucleic Acids Res 23: 5020-5026.

Decatur WA, Fournier MJ. 2002. rRNA modifications and ribosome function. Trends Biochem Sci 27: 344-351.

de Crécy-Lagard V, Brochier-Armanet C, Urbonavicius J, Fernandez B, Phillips G, Lyons B, Noma A, Alvarez S, Droogmans L, Armengaud J, et al. 2010. Biosynthesis of wyosine derivatives in tRNA: An ancient and highly diverse pathway in Archaea. Mol Biol Evol 27: 2062-2077.

Del Campo M, Recinos C, Yanez G, Pomerantz SC, Guymon R, Crain PF, McCloskey JA, Ofengand J. 2005. Number, position, and significance of the pseudouridines in the large subunit ribosomal RNA of Haloarcula marismortui and Deinococcus radiodurans. RNA 11: 210-219.

Dennis PP, Omer A. 2005. Small non-coding RNAs in Archaea. Curr Opin Microbiol 8: 685-694.

Edmonds CG, Crain PF, Gupta R, Hashizume T, Hocart CH, Kowalak JA, Pomerantz SC, Stetter KO, McCloskey JA. 1991. Posttranscriptional modification of tRNA in thermophilic archaea (Archaebacteria). J Bacteriol 173: 3138-3148.

El Yacoubi B, Phillips G, Blaby IK, Haas CE, Cruz Y, Greenberg J, de Crécy-Lagard V. 2009. A gateway platform for functional genomics in Haloferax volcanii: Deletion of three tRNA modification genes. Archaea 2: 211-219.

Fabbri S, Fruscoloni P, Bufardeci E, Di Nicola Negri E, Baldi MI, Attardi DG, Mattoccia E, Tocchini-Valentini GP. 1998. Conservation of substrate recognition mechanisms by tRNA splicing endonucleases. Science 280: 284-286.

Fruscoloni P, Baldi MI, Tocchini-Valentini GP. 2001. Cleavage of non-tRNA substrates by eukaryal tRNA splicing endonucleases. EMBO Rep 2: 217-221.

Giordano E, Peluso I, Senger S, Furia M. 1999. minifly, a Drosophila gene required for ribosome biogenesis. J Cell Biol 144: 11231133.

Grosjean H. 2005. Modification and editing of RNA: Historical overview and important facts to remember. In Fine-tuning of RNA function by modification and editing. Topics in Current Genetics (ed. H Grosjean), Vol. 12, pp. 1-22. Springer-Verlag, Berlin-Heidelberg.

Grosjean H. 2009. Nucleic acids are not boring long polymers of only four types of nucleotides: A guided tour. In DNA and RNA modifying enzymes: Structure, mechanism, function and evolution (ed. H Grosjean), pp. 1-18. Landes Bioscience, Austin, TX.

Grosjean H, Gaspin C, Marck C, Decatur WA, de Crécy-Lagard V. 2008. RNomics and Modomics in the halophilic archaea Haloferax volcanii: Identification of RNA modification genes. BMC Genomics 9: 470. doi: 10.1186/1471-2164-9-470.

Grozdanov PN, Fernandez-Fuentes N, Fiser A, Meier UT. 2009. Pathogenic NAP57 mutations decrease ribonucleoprotein assembly in dyskeratosis congenita. Hum Mol Genet 18: 4546-4551. 
Gupta R. 1984. Halobacterium volcanii tRNAs. Identification of 41 tRNAs covering all amino acids, and the sequences of 33 class I tRNAs. J Biol Chem 259: 9461-9471.

Gupta R. 1986. Transfer RNAs of Halobacterium volcanii: Sequences of five leucine and three serine tRNAs. Syst Appl Microbiol 7: 102105.

Gurha P, Gupta R. 2008. Archaeal Pus10 proteins can produce both pseudouridine 54 and 55 in tRNA. RNA 14: 2521-2527.

Gurha P, Joardar A, Chaurasia P, Gupta R. 2007. Differential roles of archaeal box H/ACA proteins in guide RNA-dependent and independent pseudouridine formation. RNA Biol 4: 101-109.

Gutgsell N, Englund N, Niu L, Kaya Y, Lane BG, Ofengand J. 2000. Deletion of the Escherichia coli pseudouridine synthase gene truB blocks formation of pseudouridine 55 in tRNA in vivo, does not affect exponential growth, but confers a strong selective disadvantage in competition with wild-type cells. RNA 6: 1870-1881.

Hamma T, Ferre-D’Amare AR. 2006. Pseudouridine synthases. Chem Biol 13: 1125-1135.

Hamma T, Ferre-D'Amare AR. 2010. The box H/ACA ribonucleoprotein complex: Interplay of RNA and protein structures in posttranscriptional RNA modification. J Biol Chem 285: 805-809.

Harrington KM, Nazarenko IA, Dix DB, Thompson RC, Uhlenbeck OC. 1993. In vitro analysis of translational rate and accuracy with an unmodified tRNA. Biochemistry 32: 7617-7622.

Hartman AL, Norais C, Badger JH, Delmas S, Haldenby S, Madupu R, Robinson J, Khouri H, Ren Q, Lowe TM, et al. 2010. The complete genome sequence of Haloferax volcanii DS2, a model archaeon. PLoS ONE 5: e9605. doi: 10.1371/journal.pone.0009605.

He J, Navarrete S, Jasinski M, Vulliamy T, Dokal I, Bessler M, Mason PJ. 2002. Targeted disruption of $D k c 1$, the gene mutated in $\mathrm{X}$-linked dyskeratosis congenita, causes embryonic lethality in mice. Oncogene 21: 7740-7744.

Heiss NS, Knight SW, Vulliamy TJ, Klauck SM, Wiemann S, Mason PJ, Poustka A, Dokal I. 1998. X-linked dyskeratosis congenita is caused by mutations in a highly conserved gene with putative nucleolar functions. Nat Genet 19: 32-38.

Holmes ML, Dyall-Smith ML. 2000. Sequence and expression of a halobacterial $\beta$-galactosidase gene. Mol Microbiol 36: 114-122.

Jiang W, Middleton K, Yoon HJ, Fouquet C, Carbon J. 1993. An essential yeast protein, CBF5p, binds in vitro to centromeres and microtubules. Mol Cell Biol 13: 4884-4893.

Joardar A, Gurha P, Skariah G, Gupta R. 2008. Box C/D RNA-guided $2^{\prime}$-O methylations and the intron of tRNA ${ }^{\text {Trp }}$ are not essential for the viability of Haloferax volcanii. J Bacteriol 190: 7308-7313.

Juhling F, Morl M, Hartmann RK, Sprinzl M, Stadler PF, Putz J. 2009. tRNAdb 2009: Compilation of tRNA sequences and tRNA genes. Nucleic Acids Res 37: D159-D162.

Kaczowka SJ, Maupin-Furlow JA. 2003. Subunit topology of two 20S proteasomes from Haloferax volcanii. J Bacteriol 185: 165-174.

Kammen HO, Marvel CC, Hardy L, Penhoet EE. 1988. Purification, structure, and properties of Escherichia coli tRNA pseudouridine synthase I. J Biol Chem 263: 2255-2263.

Karijolich J, Yu YT. 2008. Insight into the protein components of the box H/ACA RNP. Curr Proteomics 5: 129-137.

Karijolich J, Yu YT. 2010. Spliceosomal snRNA modifications and their function. RNA Biol 7: 192-204.

Kirpekar F, Hansen LH, Rasmussen A, Poehlsgaard J, Vester B. 2005. The archaeon Haloarcula marismortui has few modifications in the central parts of its $23 \mathrm{~S}$ ribosomal RNA. J Mol Biol 348: 563573.

Kiss T, Fayet-Lebaron E, Jady BE. 2010. Box H/ACA small ribonucleoproteins. Mol Cell 37: 597-606.

Knight SW, Heiss NS, Vulliamy TJ, Greschner S, Stavrides G, Pai GS, Lestringant G, Varma N, Mason PJ, Dokal I, et al. 1999. X-linked dyskeratosis congenita is predominantly caused by missense mutations in the DKC1 gene. Am J Hum Genet 65: 50-58.

Kowalak JA, Dalluge JJ, McCloskey JA, Stetter KO. 1994. The role of posttranscriptional modification in stabilization of transfer RNA from hyperthermophiles. Biochemistry 33: 7869-7876.
Kowalak JA, Bruenger E, Crain PF, McCloskey JA. 2000. Identities and phylogenetic comparisons of posttranscriptional modifications in 16 S rRNA from Haloferax volcanii. J Biol Chem 275: 2448424489.

Krasilnikov AS, Mondragon A. 2003. On the occurrence of the T-loop RNA folding motif in large RNA molecules. RNA 9: 640-643.

Lafontaine DL, Bousquet-Antonelli C, Henry Y, Caizergues-Ferrer M, Tollervey D. 1998. The box H+ACA snoRNAs carry Cbf5p, the putative rRNA pseudouridine synthase. Genes Dev 12: 527537.

Large A, Stamme C, Lange C, Duan Z, Allers T, Soppa J, Lund PA. 2007. Characterization of a tightly controlled promoter of the halophilic archaeon Haloferax volcanii and its use in the analysis of the essential cctl gene. Mol Microbiol 66: 1092-1106.

Lazaro E, Rodriguez-Fonseca C, Porse B, Urena D, Garrett RA, Ballesta JP. 1996. A sparsomycin-resistant mutant of Halobacterium salinarium lacks a modification at nucleotide U2603 in the peptidyl transferase centre of $23 \mathrm{~S}$ rRNA. J Mol Biol 261: 231-238. [Published erratum appears in J Mol Biol 1996 Dec13;264(4):839.]

Lecointe F, Namy O, Hatin I, Simos G, Rousset JP, Grosjean H. 2002. Lack of pseudouridine 38/39 in the anticodon arm of yeast cytoplasmic tRNA decreases in vivo recoding efficiency. $J$ Biol Chem 277: 30445-30453.

Li H. 2008. Unveiling substrate RNA binding to H/ACA RNPs: One side fits all. Curr Opin Struct Biol 18: 78-85.

Meier UT. 2005. The many facets of H/ACA ribonucleoproteins. Chromosoma 114: 1-14.

Meier UT. 2006. How a single protein complex accommodates many different H/ACA RNAs. Trends Biochem Sci 31: 311-315.

Meier UT, Blobel G. 1994. NAP57, a mammalian nucleolar protein with a putative homolog in yeast and bacteria. J Cell Biol 127: 1505-1514.

Mitchell JR, Wood E, Collins K. 1999. A telomerase component is defective in the human disease dyskeratosis congenita. Nature 402: 551-555.

Motorin Y, Muller S, Behm-Ansmant I, Branlant C. 2007. Identification of modified residues in RNAs by reverse transcription-based methods. Methods Enzymol 425: 21-53.

Mueller EG, Ferre-D’Amare AR. 2009. Pseudouridine formation, the most common transglycosylation in RNA. In DNA and RNA modification enzymes: Structure, mechanism, function and evolution (ed. H Grosjean), pp. 363-376. Landes Bioscience, Austin, TX.

Muller S, Fourmann JB, Loegler C, Charpentier B, Branlant C. 2007. Identification of determinants in the protein partners aCBF5 and aNOP10 necessary for the tRNA: $\Psi 55$-synthase and RNAguided RNA: $\Psi$-synthase activities. Nucleic Acids Res 35: 56105624.

Muller S, Leclerc F, Behm-Ansmant I, Fourmann JB, Charpentier B, Branlant C. 2008. Combined in silico and experimental identification of the Pyrococcus abyssi H/ACA sRNAs and their target sites in ribosomal RNAs. Nucleic Acids Res 36: 2459-2475.

Muller S, Urban A, Hecker A, Leclerc F, Branlant C, Motorin Y. 2009. Deficiency of the tRNA ${ }^{\text {Tyr }}: \Psi 35$-synthase aPus7 in Archaea of the Sulfolobales order might be rescued by the H/ACA sRNA-guided machinery. Nucleic Acids Res 37: 1308-1322.

Nagaswamy U, Fox GE. 2002. Frequent occurrence of the T-loop RNA folding motif in ribosomal RNAs. RNA 8: 1112-1119.

Namy O, Lecointe F, Grosjean H, Rousset J-P. 2005. Translational recoding and RNA modifications. In Fine-tuning of RNA function by modification and editing. Topics in Current Genetics (ed. H Grosjean), Vol. 12, pp. 309-340. Springer-Verlag, BerlinHeidelberg.

Nurse K, Wrzesinski J, Bakin A, Lane BG, Ofengand J. 1995. Purification, cloning, and properties of the tRNA psi 55 synthase from. RNA 1: 102-112.

Ofengand J, Bakin A. 1997. Mapping to nucleotide resolution of pseudouridine residues in large subunit ribosomal RNAs from representative eukaryotes, prokaryotes, archaebacteria, mitochondria and chloroplasts. J Mol Biol 266: 246-268. 
Ofengand J, Del Campo M, Kaya Y. 2001a. Mapping pseudouridines in RNA molecules. Methods 25: 365-373.

Ofengand J, Malhotra A, Remme J, Gutgsell NS, Del Campo M, JeanCharles S, Peil L, Kaya Y. 2001b. Pseudouridines and pseudouridine synthases of the riobosome. Cold Spring Harb Symp Quant Biol 66: 147-159.

Peattie DA. 1979. Direct chemical method for sequencing RNA. Proc Natl Acad Sci 76: 1760-1764.

Phillips B, Billin AN, Cadwell C, Buchholz R, Erickson C, Merriam JR, Carbon J, Poole SJ. 1998. The Nop60B gene of Drosophila encodes an essential nucleolar protein that functions in yeast. Mol Gen Genet 260: 20-29.

Roovers M, Hale C, Tricot C, Terns MP, Terns RM, Grosjean H, Droogmans L. 2006. Formation of the conserved pseudouridine at position 55 in archaeal tRNA. Nucleic Acids Res 34: 4293-4301.

Ruggero D, Grisendi S, Piazza F, Rego E, Mari F, Rao PH, CordonCardo C, Pandolfi PP. 2003. Dyskeratosis congenita and cancer in mice deficient in ribosomal RNA modification. Science 299: 259-262.

Sambrook J, Russell DW. 2001. Molecular cloning: A laboratory manual. Cold Spring Harbor Laboratory Press, Cold Spring Harbor, NY.

Singh SK, Gurha P, Tran EJ, Maxwell ES, Gupta R. 2004. Sequential $2^{\prime}$-O-methylation of archaeal pre-tRNA ${ }^{\text {Trp }}$ nucleotides is guided by the intron-encoded but trans-acting box $\mathrm{C} / \mathrm{D}$ ribonucleoprotein of pre-tRNA. J Biol Chem 279: 47661-47671.

Tatusov RL, Fedorova ND, Jackson JD, Jacobs AR, Kiryutin B, Koonin EV, Krylov DM, Mazumder R, Mekhedov SL, Nikolskaya AN, et al. 2003. The COG database: An updated version includes eukaryotes. BMC Bioinformatics 4: 41-54.

Urbonavicius J, Auxilien S, Walbott $\mathrm{H}$, Trachana K, GolinelliPimpaneau B, Brochier-Armanet C, Grosjean H. 2008. Acquisition of a bacterial RumA-type tRNA(uracil-54, C5)-methyltransferase by Archaea through an ancient horizontal gene transfer. Mol Microbiol 67: 323-335.

Waas WF, de Crécy-Lagard V, Schimmel P. 2005. Discovery of a gene family critical to wyosine base formation in a subset of phenylalanine-specific transfer RNAs. J Biol Chem 280: 37616-37622.

Watanabe M, Matsuo M, Tanaka S, Akimoto H, Asahi S, Nishimura S, Katze JR, Hashizume T, Crain PF, McCloskey JA, et al. 1997. Biosynthesis of archaeosine, a novel derivative of 7-deazaguanosine specific to archaeal tRNA, proceeds via a pathway involving base replacement on the tRNA polynucleotide chain. J Biol Chem 272: 20146-20151.

Wu G, Xiao M, Yang C, Yu YT. 2011. U2 snRNA is inducibly pseudouridylated at novel sites by Pus7p and snR81 RNP. EMBO J 30: 79-89.

Yarian CS, Basti MM, Cain RJ, Ansari G, Guenther RH, Sochacka E, Czerwinska G, Malkiewicz A, Agris PF. 1999. Structural and functional roles of the N1- and N3-protons of $\Psi$ at tRNA's position 39. Nucleic Acids Res 27: 3543-3549.

Yu YT, Terns RM, Terns MP. 2005. Mechanisms and functions of RNA-guided RNA modification. In Fine-tuning of RNA functions by modification and editing (ed. H Grosjean), pp. 223-262. SpringerVerlag, New York.

Zebarjadian Y, King T, Fournier MJ, Clarke L, Carbon J. 1999. Point mutations in yeast CBF5 can abolish in vivo pseudouridylation of rRNA. Mol Cell Biol 19: 7461-7472.

Zerfass K, Beier H. 1992. Pseudouridine in the anticodon GWA of plant cytoplasmic tRNA $^{\text {Tyr }}$ is required for UAG and UAA suppression in the TMV-specific context. Nucleic Acids Res 20: 5911-5918.

Zhou J, Liang B, Li H. 2011. Structural and functional evidence of high specificity of Cbf5 for ACA trinucleotide. RNA 17:244-250. 

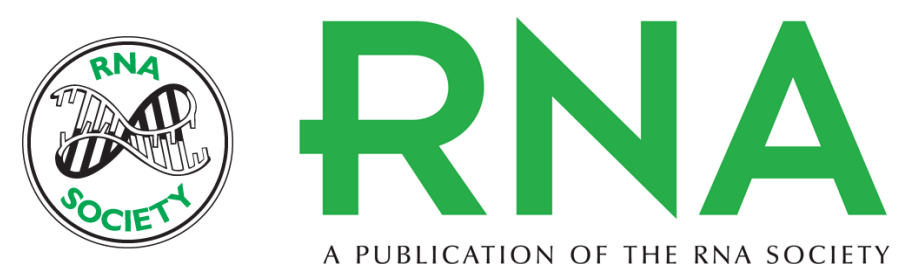

A PUBLICATION OF THE RNA SOCIETY

\section{Pseudouridine formation in archaeal RNAs: The case of Haloferax volcanii}

Ian K. Blaby, Mrinmoyee Majumder, Kunal Chatterjee, et al.

RNA 2011 17: 1367-1380 originally published online May 31, 2011

Access the most recent version at doi:10.1261/rna.2712811

\section{Supplemental http://rnajournal.cshlp.org/content/suppl/2011/05/10/rna.2712811.DC1 \\ Material}

References This article cites 85 articles, 31 of which can be accessed free at:

http://rnajournal.cshlp.org/content/17/7/1367. full.html\#ref-list-1

\section{License}

Email Alerting Receive free email alerts when new articles cite this article - sign up in the box at the Service top right corner of the article or click here. 